\author{
Љиљана В. Ђурић \\ Филолошки факутет Универзитета у Београду \\ djuricz@sbb.rs
}

\title{
НАСТАВНИ ПРОГРАМ СТРАНОГ ЈЕЗИКА ЗА ГИМНАЗИЈУ: АНАЛИЗА КОНЦЕПЦИЈЕ КАО ВИД ЕВАЛУАЦИЈЕ $A$ POSTERIORI
}

\section{Сажетак}

Рад је посвећен анализи наставног програма страног језика за гимназију који је у Србији на снази већ преко двадесет година. Поред његових лингвистичких и психопедагошких теоријских основа, истражује се и унутарња кохерентност, а посебна пажња поклања се развијању способности разумевања говора као елементу који са комуникативним приступом доживљава значајну концепцијску промену; наставни програм за први страни језик пореди се са оним за други страни језик.

Даља анализа бави се интерпретацијом наставног програма (посебно сегмента који се односи на разумевање говора), то јест начином на који га тумаче домаћи издавач уџбеничке литературе и аутори уџбеника француског језика.

Кључне речи: страни језици у Србији - евалуација наставног програма за гимназију - разумевање говора - концепција уџбеника француског језика

\section{1. УВОД}

Наставни програм страног језика за гимназију у Србији, чијој је анализи посвећен овај рад, на снази је већ пуних двадесет година; може се сматрати изузетно дуговечним, посебно ако се упореди са наставним програмом за основну школу који је у више наврата мењан, некада незнатно, а некада у

1 Рад се ослања на резултате истраживања вршених за потребе израде магистарског рада Разумевање говора: од теорије до наставе франиуског језика као страног, одбрањеног октобра 2008. године на Филозофском факултету Универзитета у Новом Саду под менторством проф. др Снежане Гудурић. 
значајној мери, будући да су промене обухватале и измену наставног плана, као и увођење другог страног језика као обавезног изборног наставног предмета. ${ }^{2}$ Просветне власти наше земље најављују већ неколико година израду стратегије развоја гимназије а затим и нових наставних програма. Имајући у виду значај тог задатка, којем би ваљало приступити са што јаснијим представама о ономе што треба мењати и о начину на који треба извршити промене, ова анализа може представљати вид евалуације a posteriori важећег наставног програма и, као таква, допринети његовом нужном преиспитивању.

Анализу вршимо имајући пре свега у виду ширу концепцију образовања којом је наставни програм био условљен у тренутку његове израде. Будући, међутим, да је и даље на снази - и представља, дакле, основ за израду наставних материјала и за осмишљавање наставе - нужно је, макар и у најгрубљим цртама, разматрати и степен његове актуелности полазећи од следећег питања: да ли ученицима обезбеђује стицање и неговање способности као што су креативност, флексибилност, прилагодљивост, способност решавања проблема и учења, које су у основи појма доживотног образовањ $а$, а који је, опет, услов за стварање друштва знања - данас једног од кључних појмова за дефинисање новог типа друштвене организације у којој интелектуалне снаге имају примат у односу на производне.

Поставили смо себи задатак да истражимо како лингвистичке и психопедагошке теоријске основе тако и унутарњу кохерентност наставног програма за страни језик; поред тога, наставни програм за први страни језик поредимо са наставним програмом за други страни језик.

Посебну пажњу у анализи поклањамо развијању способности разумевања говора. Начин развијања ове способности, наиме, у великој мери представља одраз различитих теоријских поставки у глотодидактици, заснованих на различитом поимању природе језика и природе учења и наставе језика. Тако, уколико бисмо се задржали само на 20. веку, уочавамо да у настави страних језика развијање способности за ефикасно упражњавање ове језичке активности добија на значају у оквиру метода које на прво место стављају усвајање говорног језика: директна метода, аудио-орална, и посебно, аудио-визуелна глобално-структурална метода. ${ }^{3}$ У том погледу, веће концепцијске промене у

2 Правилником о наставном плану за други циклус основног образовања и васпитаға и наставном програму за пети разред основног образовања и васпитања (Просветни гласник број 110-00-00083/2007-02) овај наставни предмет уведен је 2007. године у пети разред основне школе са фондом од по два часа недељно (укупан фонд је 284 школска часа).

3 Захваљујући овој последњој, која се развија у периоду после Другог светског рата, техничка средства (магнетофон, грамофон) шире се уводе у наставни процес (Точанац-Миливојев 1997: 11-26), значајно га мењајући: могућност да на часу страног језика чују изворног говорника постаје реална за све ученике/студенте. 
настави страних језика наступају у оквиру комуникативног приступа, заснованог на поимању језика као средства комуникације и на поимању учења језика као процеса генерализације правила датог језика уз стално преструктурисање међујезика (Santos Gargallo 1999: 67-78). И овај приступ, као и поменуте методе ${ }^{4}$ у први план стављају усмени дијалог у свакодневним ситуацијама, елиминишући истовремено књижевни текст који је, као полазни материјал за наставу, (био) доминантан у граматичко-преводном методу.

Зато у даљој анализи наставног програма, коју вршимо кроз призму интерпретације домаћег издавача Завода за уџбенике и наставна средства и аутора уџбеника француског језика, трагамо за свим што се односи на разумевање говора.

\section{2. НАСТАВНИ ПРОГРАМИ СТРАНОГ ЈЕЗИКА ЗА ГИМНАЗИЈУ У РЕПУБЛИЦИ СРБИЈИ}

Наставни програми страних језика могу се анализирати на различите начине, на основу различитих критеријума и помоћу различитих метода. Најчешће, класификације се врше на основу лингвистичких и психолингвистичких теорија које су у основи одређеног програма, па говоримо, на пример, о структуралном програму, о појмовно-функционалном, о програму заснованом на комуникативном приступу. Програме намењене учењу страних језика, који су били на снази шездесетих и седамдесетих година двадесетог века, Стревенс (Strevens in Girard et al. 1988: 10-13) дели у три категорије на основу три врсте утемељења:

- лингвистичког;

- ситуационог;

- појмовно-семантичког.

4 Код утврђивања места које разумевање говора заузима у различитим методама и приступима у учењу страних језика, Жермен (Germain, Claude) методе и приступе карактеристичне за 20. век сврстава у три основна правца: интегративни (аудио-орална метода и структурално-глобална аудио-визуелна метода), лингвистички (ситуациона метода и комуникативни приступ) и психолошки (природни приступ и приступи засновани на разумевању). Док се код прве три методе предност даје настави говора - уз претежну оријентацију, у наставној пракси, ка усвајању језичких структура, стицању аутоматизама и подражавању, код сва три наведена приступа уочава се придавање већег значаја самом разумевању говора: - у комуникативном приступу, у којем је језик схваћен као средство друштвене интеракције, истиче се значај стварне комуникације саговорника и заједничког изналажења смисла (négociation du sens); - у природном приступу, развијање рецептивних способности претходи развијању продуктивних способности; - у приступима заснованим на разумевању, разумевање је прва етапа учења, а у средишту приступа су ученик и процес учења (Germain 2007: 137-310). 
Ричардс и Роџерс (Richards, Rodgers in Girard et al. 1988: 11-12) говоре, пак, о различитим приступима у изради програма, тачније о:

- структуралном приступу, у којем је језик схваћен као систем структурално повезаних елемената, а учење језика као усвајање тих елемената дефинисаних у виду граматичких јединица (као што су клауза или синтагма) и граматичких операција (као што су допуњавање, спајање итд);

- функционалном приступу, у којем је тежиште пре на семантичком него на граматичком потенцијалу језика, а учење језика је засновано на његовим функционалним категоријама;

- интеракционом приступу, који у први план ставља језичку реализацију односа међу појединцима, а учење језика види као савладавање извесног броја модела вербалне размене или оног садржаја који се дефинише у оквиру интеракције ученика као саговорника.

Вилкинс (Wilkins in Girard et al. 1988: 14,15) сматра да се сви програми могу поделити на синтетичке и аналитичке:

- програми засновани на синтетичком приступу, по њему, јесу они који предвиђају кумулативну прогресију; учење значи савладавање ограниченог броја граматичких и лексичких јединица, а од ученика се очекује да поново синтетизује тај језички материјал који је, за потребе програма, изабран, рашчлањен и поређан на основу формалних критеријума;

- програми засновани на аналитичком приступу теже, пре свега, стварању модела понашања усклађеног са циљем комуникације (исказаног у виду говорних чинова); од ученика се очекује да користећи своје аналитичке способности увиди најбитније лингвистичке компоненте вербалне размене; за ове програме (на пример појмовно-функционалне и ситуационе) веома је значајно дефинисање циљева који су изражени кроз вештине; језичка грађа класификује се на основу семантичких критеријума, а њен распоред врши се на основу појмовних потреба ученика, без наметања било каквог унапред утврђеног низа граматичких структура.

Споменућемо, такође, и типологију наставних програма страних језика коју нуди Заједнички европски оквир за живе језике: учење, настава, оијељивање (у даљем тексту ЗЕО). По ауторима тог документа, наставни програми могу бити (3ЕО 2003: 14):

- глобални - уколико теже подједнаком напретку ученика у свим областима језичке и комуникативне компетенције;

- модуларни - развијају компетенције ученика у ограниченом оквиру ради постизања јасно постављеног циља;

- пондерисани - способности се развијају неједнако, чиме се формира специфичан профил ученика (на пример: развијеније рецептивне способности); 
- парцијални - развијају само једну способност (на пример, разумевање говора).

Имајући у виду различите нивое на којима се карактеристике наставног програма могу посматрати, као и чињеницу да наставни програм страног језика који се реализује у државним школама, за разлику од оног за течајеве, не настаје као самосталан текст већ је део шире концепције државног образовања, определили смо се за следећи приступ:

- прво разматрамо општу концепцију наших наставних програма која је у непосредној вези са концепцијом образовања у оквиру које је програм донет;

- истражујемо, затим, степен унутарње кохерентности различитих елемената наставног програма за гимназију;

- вршимо поређење програма за први страни језик са програмом за други страни језик;

- потом анализирамо заступљеност разумевања говора у различитим сегментима програма, посматрајући га као један од показатеља поимања језика и начина учења језика.

Шири поглед на питање анализе било ког наставног програма указује да већ сам тај појам, наставни програм, који је дубоко укорењен у образовну културу наше земље и који се код нас и даље користи, подразумева одређену концепцију образовања и разликује се, на пример, од појма курикулум; 5 та два појма често су у конкуренцији, како у научно-стручној литератури тако и у широј употреби, а разликују се по томе што су у наставном програму дефинисани унапред, као обавезујући (док се званично не промене) и исти за све ученике и наставнике, циљеви наставног предмета, наставни садржаји и поступци у настави; много флексибилнији појам представља курикулум који, према широко прихваћеној дефиницији, „подразумева све садржаје, процесе и активности усмерене на остваривање циљева и исхода образовања и који су прописани и регулисани како на централном (националном) тако и на школском (локалном) нивоу" (Комисија за развој школског програма 2003: 109); када су језици у питању, курикулум омогућује да се узму у обзир стварне потребе ученика и може имати, стога, различите карактеристике - у зависности од статуса језика за који је сачињен и од наставног контекста у којем се остварује (Cuq 2003: 64).

Унутарњој анализи, којом сагледавамо декларативну и стварну методолошку оријентацију програма пре свега кроз усклађеност циљева и зада-

5 У научној и стручној литератури присутан је и термин силабус, који се код нас користи како у значењу детаљног описа садржаја курикулума тако и у значењу наставни план. 
така са предвиђеном прогресијом, препорученим врстама текстова и медија, и, за нас посебно занимљивим, местом које разумевање говора заузима у односу на друге елементе, мора претходити напомена да програми страних језика поседују концепцијска својства заједничка свим програмима који су на снази у гимназији, без обзира на наставни предмет. Подвући ћемо, стога, неке њихове опште карактеристике цитирајући мишљење Комисије за развој школског програма, коју је Министарство просвете Републике Србије формирало марта 2002. године са задатком да предложи нову стратегију развоја школског програма. ${ }^{6}$

Имајући у виду изразиту централизованост система образовања Србије, током деведестих година 20. века (наставни програм страних језика за гимназије - Програм за први страни језик и Програм за други страни језик - који је до данас на снази, објављен је 1990. године и 1991. године), не изненађују следеће констатације које се генерално односе на наставне планове и програме: „Тренутно, наставне планове и програме за сваки предмет, на предлог одговарајућих комисија, доноси министар просвете. Наставни садржаји, одређени и регулисани планом и програмом, обавезни су у сваком погледу, за све наставнике, све школе (истог нивоа и врсте) и све ученике. [...] У програмима (посебно оним за више разреде) скоро да уопште нема покушаја повезивања садржаја програма са животним искуством деце, као што су ретки и покушаји да се наставни садржаји повежу с њиховом могућом применом у ваншколском контексту.[...] Наставни програми, даље, обавезношћу и преобимношћу нарушавају дидактичко-методичку аутономију и тиме додатно пасивизују наставнике; смањујући простор за истраживање, промишљање и повезивање, пасивизују и ученике.” (Комисија за развој школског програма 2003: 15).

Наша глобална анализа програма страних језика за гимназију наводи нас да неке његове битне карактеристике опишемо на следећи начин:

- у питању је програм хуманистичког утемељења са изразито академским амбицијама, у чијем средишту су пре свега садржаји академске дисциплине, а у мањој мери, и углавном декларативно, процес и ефекти учења;

6 Своје ставове и решења, објављене у публикацији Реформа образовања у Републици Србији: Школски програм - кониепщија, стратегија, имплементација, Комисија је утемељила с једне стране на искуствима и традицији образовања у нашој земљи, и, с друге стране, на објективним анализама нашег система образовања и показатељима о стању у којем се налази (нпр. тематски прегледи УНИЦЕФ-а и ОЕЦД-а), на међународним искуствима у области реформи образовања, као и на резлутатима Разговора о реформи, вођених широм Србије у јесен 2001. године. 
- затвореност програма у односу на наставу других језика и других наставних предмета стварна је и очигледна нигде нису формулисани циљеви средњег образовања7 ${ }^{7}$ или образовања у гимназији, нити су игде формулисани општи циљеви наставе језика - матерњег, страних, латинског ${ }^{8}$ који су обавезни наставни предмети у гимназији; ${ }^{9}$

- циљеви наставног предмета страни језик веома су широко, идеалистички, непрагматично формулисани (циљ програма за први страни језик: „Циљ наставе страних језика је стицање, проширивање и продубљивање знања и умења у свим језичким активностима, упознавање културног наслеђа створеног на датом језику и оспособљавање за даље образовање и самообразовање”; циљ програма за други страни језик: „Циљ наставе другог страног језика је стицање нових знања и овладавање новим језичким системом што доприноси проширивању и богаћењу општих изражајних и интелектуалних могућности ученика, упознавање културе, обичаја, и начина живота народа чији се језик учи као и развијање естетских и моралних вредности”);

- циљеви су декларативни: не регулишу наставни процес и углавном не омогућују стицање применљивих знања; доводе, пак, до појаве такозваних скривених ефеката образовања, на пример до формирања пасивног става према учењу и употреби језика, до губитка мотивације за даље учење или до негативног односа према одређеном језику (што свакако није дефинисано као циљ наставе страних језика);

- тежиште програма је на граматичким садржајима, који су детаљно побројани у складу са структуралистичким виђењем језика, а не на очекиваним исходима или резултатима наставе формулисаним у категоријама које би описивале опазиво понашање ученика;

- програм не ствара предуслове за стицање методолошке компетенције ученика (развијање способности учења језика);

- методички савети упућени наставницима, дати у виду „упутства”, не омеђују јасно простор аутономије наставника, онај простор који би му омогућио да наставу примери стварним потребама и интересовањима ученика;

7 У члану 2 Закона о средњем образовању (усвојеном 1992. године) каже се: „У школи се стичу општа и стручна знања и способности за даље школовање, односно за рад, заснована на достигнућима науке, технологије, културе и уметности; стиче васпитање; негују моралне и естетске вредности; развијају физичке и духовне способности личности; свест о хуманистичким вредностима, личној и друштвеној одговорности и негује заштита здравља."

8 Реч је овде о стицању језичке компетенције која се огледа у способности употребе усменог и писаног језика, матерњег и страног, адекватно ситуацији и захтеву који се пред учеником поставља.

9 Са изузетком Математичке гимназије у којој се учи само један страни језик. 
- програм не нуди јасне критеријуме за систематско праћење и вредновање реализације постављених циљева. ${ }^{10}$

Истраживање унутарње кохерентности наставног програма страних језика обавили смо посматрањем декларисане методолошке оријентације, предвиђене прогресије, врста текстова и медија који се препоручују, као и експлицитно или имплицитно формулисаних ефеката наставе. У тексту програма анализирали смо посебно брижљиво оне делове у којима смо нашли информације у вези са поменутим показатељима.

Први утисак који стичемо читањем наставног програма за стране језике у гимназији јесте да је у питању богат, помало еклектичан, али полицентричан ${ }^{11}$ програм у којем нису занемарени ни наставници, ни ученици, ни садржаји наставне дисциплине; да је дато довољно места и знањима из језика, и онима из културе народа чији се језик учи; да је савремен, јер упућује на тематику из савременог живота и стваралаштва, као и на употребу медија и аудио-визуелних материјала.

Подробнија анализа ипак показује недоследности које су бројне и видљиве већ и ако се прочитају сегменти које смо издвојили и унели у табеле. Истаћи ћемо само неколико примера:

- у циљу наставног програма, првог и другог страног језика, нигде се изричито не говори о развијању способности комуникације или споразумевања на датом језику (можда због заблуде да је у питању способност ниже вредности, „вештина”, која је недостојна образовне установе као што је гимназија); неки други сегменти програма, названи на пример Стандарди, ${ }^{12}$

10 Неки од недостатака овакве концепције наставног програма отклоњени су, када је реч о страном језику као обавезном предмету у основној школи, 1998. и 1999. године. У тада израђеном Предлогу новог програма постављен је нови циљ наставе страног језика; задаци су замењени очекиваним постигнућима, опративни задации дати су по језичким активностима, осавремењена је тематика, уведен је сегмент који се односи на познаваъе иивилизаиије, као и сегмент који се тиче учењ а учењ $а$ страног језика. Граматички садржаји, такође, донекле су измењени: везани су за комуникативне функције и илустровани су примерима реализације. Иако тај наставни програм никада није ступио на снагу, он је послужио као једна од основа за програме рађене у оквиру реформе образовања (па и за оне након обустављања реформе 2004. године).

11 Појам полицентризма у наставним програмима страних језика везан је за прогресију и дугујемо га Лују Поршеу; у новије време њиме се бавио и Серж Борг (Serge Borg): Pour une lecture polycentrique de la notion de progression, in Coste D, Véronique D, coord. (2000). La notion de progression (132-143), Notions en Question, ENS de Fontenay-Saint-Cloud, Paris 3-Sorbonne nouvelle. (in Cuq, Gruca 2005: 195).

12 Напомињемо да оно што је дато нису стандарди у смислу у којем се овај појам најчешће користи. Под тим појмом подразумева се „дефинисани, усаглашени и општеприхваћени ниво остварености [....]”. Министарсво просвете и спорта РС и Британски савет 2005, Приручник за самовредновағе и вредносвање рада школе. 
предвиђају, с друге стране, врло конкретне резултате наставе у смислу способности употребе језика, истини за вољу, без експлицитног разврставања по језичким активностима и недовољно спецификоване у погледу очекиваног нивоа - на пример: „ученик треба да се оспособи за преношење, превођење и тумачење порука; пише саставе (опис, препричавање, извештавање, молба)", итд; истовремено, језички садржаји описују граматичке категорије које ни на који начин нису доведене у везу са комуникативним функцијама или са постављеним задацима/стандардима;

- иако је у време израде програма појам нивоа био већ добро познат и разрађен у глотодидактици (први прагови знања, за енглески и француски језик, израђени су почетком седамдесетих година 20. века, а за оне који се баве наставом француског језика за питање нивоа врло поучна публикација Vers un niveau 3, Recherches et applications, специјални број стручног часописа Le Français dans le Monde, објављена је марта 1987. године), очекивани ниво комуникативне компетенције се не дефинише; штавише, збуњујуће је да се у истом разреду, од истих ученика (III разреда друштвено-језичког смера, на пример) очекује да читају књижевна дела као што је песма Correspondances Шарла Бодлера - што не могу ни сви изворни говорници француског језика, да преводе, усмено и писмено, краћа саопштења и разговоре - што не могу увек ни студенти француског језика и књижевности, али и да попуњавају формуларе - што је један од задатака који са лакоћом савладавају почетници на првим часовима француског језика;

- прогресија се описује као линеарно-спирална у програму за први страни језик (у програму за други страни језик каже се да је она кумулативна, а за неке делове програма да је конципирана у виду концентричних кругова), што је у програмима страних језика неуобичајено и делује такође као компромис, а не као доследно методолошко опредељење; познато је, наиме, да је све до појаве аудио-оралне и структурално-глобалне аудио-визуелне методе претежно била заступљена линеарна прогресија, углавном граматичких и лексичких елемената програма (од лакшег ка тежем, од простог ка сложеном, од сличног ка различитом, од правилног ка неправилном, од корисног ка споредном) (Cuq, Gruca 2005: 193, 194); комуникативни приступ, чији су елементи декларативно унети у наставни програм гимназије, представља у теоријском смислу континуитет функционално-појмовног приступа о којем је већ било речи, и предвиђа спиралну прогресију (са честим враћањем на обрађено градиво, уз обогаћивања и продубљивања), а никако линеарну која је у супротности са његовом концепцијом заснованом на идеји да је за учење језика битнији комуникативни аспект елемената језика него формално-граматички (Cuq 2003: 179, 204, 205). 
Поређење наставног програма другог страног језика са наставним програмом првог страног језика не пружа нам јасну слику о представи коју су аутори имали у погледу њихове могуће диференцијације; осим помињања у Упутству програма другог страног језика, „раније стеченог искуства”, које, уз „узраст ученика, омогућује интензивније и ефикасније учење” (не каже се како наведени фактори томе доприносе и који поступци у настави томе служе), разлике су незнатне и видљиве само у опису граматичких садржаја (нешто мање захтевних у програму за други страни језик), броју речи које треба савладати (1200 у програму за први страни језик и 1400 у програму за други страни језик) и у делимично различитој тематици (у програму за први страни језик, посебно у сегменту Из савременог живота и тековина културе народа чији се језик учи и наших народа, предвиђена је веома захтевна тематика, као на пример ,значајни историјски догађаји, разни видови уметничког и научног стваралаштва", што није случај са програмом за други страни језик) (Ђурић 2000: 36, 37). Напомињемо, такође, да сегмент Стандарди није дат у програму за други страни језик.

Пажљивом анализом увиђамо, дакле, да је овај програм претежно лингвистички, заснован на структуралистичком виђењу језика, синтетички у смислу који том изразу даје Вилкинс; „елементи комуникативног приступа" који су уведени, рекло би се, ради осавремењивања, чине га суштински некохерентним и збуњујућим. О мотивима таквог опредељења није могуће говорити; о њима би нас могли обавестити само аутори програма (да ли је у питању свестан компромис стручњака са различитим виђењима природе језика, потреба ученика у гимназији и учења језика? Или је можда пресудно утицала одређена представа аутора програма о пожељном елитизму гимназије који је у том тренутку требало као образовну установу обновити? Подсећамо да је тим наставним програмом укинуто непопуларно усмерено средње образовање, те је тако схваћено елитистичко усмерење гимназијског образовања имплицитни стратешки циљ реформатора). Какав год, дакле, да је разлог тих опредељења, мора се констатовати да је 1990. и 1991. године објављен веома дуговечан наставни програм који је, стицајем политичких околности, на снази већ 20 година; његова недоследност, штавише контрадикторност, учиниле су га неприменљивим у целини, то јест, подложним деформишућим интерпретацијама, како аутора уџбеника тако и наставника, о чему ћемо више рећи у анализи уџбеника за трећи и четврти разред гимназије. 


\section{3. РАЗВИЈАЮЕ СПОСОБНОСТИ СЛУШАЮА И РАЗУМЕВАЮА ГОВОРА У НАСТАВНИМ ПРОГРАМИМА СТРАНОГ/ ФРАНЦУСКОГ ЈЕЗИКА ЗА ГИМНАЗИЈУ У РЕПУБЛИЦИ СРБИЈИ}

Будући да су у наставном програму страних језика по језицима дати искључиво граматички садржаји и наслови дела за лектиру - што није централна тема нашег истраживања, на овом месту ћемо разматрати заједничке делове програма то јест елементе програма који су у вези са разумевањем говора, као и оне који се односе на рецепцију уопште.

Разумевање говора заступљено је у наставном програму за гимназију, ${ }^{13}$ у већој мери у програму за први страни језик, у скромнијем обиму у програму за други страни језик: иако то није експлицитно речено, разумевање говора је у датој концепцији виђено као нека врста круне знања, а не као почетни стадијум учења језика и услов за даље напредовање. Ту разлику између програма за први и програма за други страни језик не можемо, ипак, подвести под концепцијску диференцијацију два програма: у питању је, наиме, само унеколико различит обим, а никако и идеја, која би иначе била сасвим оправдана, да наставни програм другог страног језика буде глобалног типа и да се његовом применом негују у истој мери све четири основне језичке способности, док би програм првог страног језика био пондерисаног типа и неговао рецептивне способности на високом нивоу, а на нешто нижем - продуктивне.

Иако је разумевање говора присутно у програму, није му дат онај значај који би омогућио постизање вишег нивоа знања страног језика, како је истакнуто у циљу програма за гимназију. Будући да нема никаквих ближих одређења у смислу врсте, дужине и сложености текстова који се слушају, начин развијања способности разумевања говора изгледа да је дат наставнику у искључиву надлежност: наставник, којем је иначе прописано све друго до детаља, треба, када је у питању развијање способности разумевања говора, да осмисли прогресију, да изврши одабир и дидактизацију аудио и видео материјала, да конципира провере објективног типа ради вредновања разумевања, да мотивише ученике да, „као својеврстан и сталан домаћи задатак”, прате [...] „одабране филмове и емисије на телевизији и радију”. Видимо, дакле, да и у овом аспекту наставни програм делује збуњујуће због великог раскорака који постоји између циљева и задатака, објашњења/начина остваривања програма, предвиђеног наставног плана и услова за реализацију програма. Рецептивно знање око 2600 (и више) речи и израза (што је захтев

13 Морамо напоменути, такође, да су делови текста које смо ми унели у две табеле - на две и по стране - расути у наставном програму на 44 стране, то јест на 88 стубаца! 
програма за први страни језик након 670 до 870 школских часова наставе), ${ }^{14}$ или око 1400 речи и израза (што је захтев програма за други страни језик након 280 школских часова наставе), никако не омогућује да ученици првог страног језика ,„репродукују и резимирају било одслушан или прочитан текст, оспособе се за преношење и тумачење порука", или да ученици другог страног језика „слушају изворног говорника, текст, као и информације, преко медија (радио, ТВ итд.).” Способност реализације прво поменуте језичке активности, коју називамо медијација, по ауторима публикације Vers un niveau 3 представља управо карактеристику високог нивоа знања којим се онај ко учи језик приближава компетенцији изворног говорника, што се постиже тек након (најмање) 800 сати учења језика - то јест око 1000 школских часова); праћење медија, без прецизирања дужине и сложености текста, могуће је тек када се постигне праг знања, за шта је потребно око 400 сати учења језика то јест, око 500 школских часова.

Нереални захтеви, недефинисани у погледу нивоа постигнућа, начина постизања циљева и услова за њихову реализацију, и овај сегмент програма чине неспроводивим у настави; чињеница да школска надзорница за француски језик, од 1996. до 2007. године, ни на једном часу француског језика није присуствовала реализацији било какве наставне активности усмерене на развијање способности разумевања говора, потврђује овај наш закључак.

Анализу наставног програма за гимназију завршићемо следећом напоменом: наш критички став у односу на анализирани програм односи се на његову недоследност, на неспремност аутора да јасно формулишу циљеве наставе, ${ }^{15}$ на оглушивање о оно што је у глотодидактици у време када је писан било већ добро познато и широко прихваћено. Из те критике, међутим, не треба закључити да заговарамо развијање искључиво комуникативне компетенције у настави страних језика у гимназији. Упознавање језика као

14 У основној школи до 2007. године фонд је био 390 школских часова; томе додајемо 384 у гимназији општег типа (укупно 774); 489 на друштвено-језичком смеру (укупно 879); 280 на природно-математичком смеру (укупно 670).

15 Слично мишљење изнео је и професор Драган Крстић који је сматрао да „Филолошки факултет, делимично Филозофски факултет, затим Филолошка гимназија [...] уче стране језике као дисциплине мишљења, док многобројне школе страних језика уче свакодневни говор (са редукованом граматиком, синтаксом и лексиком) као страни језик. Наше основне и средње школе, међутим, налазе се негде између и та неодређеност положаја наставе страних језика мора се сматрати једним од најглавнијих разлога скромних резултата наставе, несразмерних улагањима друштва, ученика и родитеља" (Крстић 2000: 149). Иако се, по нашем мишљењу, са тврдњом из прве реченице овог цитата може полемисати, сматрамо да је у другој реченици изречена велика истина, не због тога што паралелни развој комуникативне компетенције и спознаје језика као система не би били могући, већ зато што је и у програму и у настави потребно њихово јасно разграничење. 
система неопходно је на том узрасту (па чак и раније), али уз обавезно јасно указивање на оно што је у настави граматике у служби развоја комуникативне компетенције и на оно што је у служби рефлексије (а не декларативних знања) и концептуализације језичких феномена.

\section{4. РАЗВИЈАЮЕ СПОСОБНОСТИ СЛУШАҢА И РАЗУМЕВАЮА ГОВОРА У ДОМАЋИМ УЏБЕНИЦИМА ФРАНЦУСКОГ ЈЕЗИКА ЗА ТРЕЋИ И ЧЕТВРТИ РАЗРЕД ГИМНАЗИЈЕ}

„Уџбеник, а овде подразумевамо и све оно што га прати (свеске, приручници, аудио или видео касете), као основни извор сазнавања има значаја у настави страног језика више него у настави било ког другог предмета: један читав свет, са његовом свеукупном традицијом и културом обухваћен је том књигом помоћу које ученик усваја програмски прописана знања. Између тог света из књиге [...] и објективизације сазнања о њему стоји само наставник. Стога се морамо сложити да уџбеник представља окосницу од које полазе и којој се враћају и наставници и ученици. Из тог разлога њему морамо посветити посебну пажњу:" (Точанац 2000: 141).

Овим редовима о значају уџбеника страног језика можемо додати само неколико речи: његова важност у нас посебно је била велика током деведесетих година 20. века када је, због изолације наше земље и немаштине школа и наставника, представљао, поред наведеног у цитату, и замену за стручно усавршавање, то јест, био често једини извор нових сазнања наставника страног језика како у области развоја глотодидактике тако и у области цивилизације и развоја језика.

Иако би због наведених разлога свеобухватна анализа уџбеника била веома корисна за разумевање стања ствари у настави страних језика у нашим државним школама, потребе нашег рада ограничавају нас на тражење обавештења о томе да ли је, и на који начин, у њима предвиђено развијање способности разумевања говора.

Анализирали смо уџбенике за трећи и четврти разред гимназије (и то за учење које представља континуитет програма за основну школу, и за учење које почиње у првом разреду гимназије) како бисмо добили одговоре на следећа питања:

1. Да ли је у уџбенику предвиђено развијање способности разумевања говора, и ако јесте, у ком обиму, на који начин, помоћу каквих наставних активности, на основу каквог звучног/видео материјала? 
2. Ако није, да ли се, уз одређене сугестије, развијање те способности експлицитно поверава наставнику?

Коментари и закључци које ћемо даље у тексту изнети настали су на основу посматрања следећих показатеља: - елементи уџбеничког комплета; - изложена концепција; - врсте текстова; - развијање способности разумевања говора; - виђење говорног језика.

a) Уџбеници по наставном програму за први страни језик (и за други страни језик када се наставља учење започето у основној школи) јесу:

- за трећи разред гимназије De quoi parle-t-on aujourd'hui? аутора др Наде Петровић (Завод за уџбенике и наставна средства, Београд), чије прво издање датира из 1994, а пето издање, које смо анализирали, из 2004. године; ${ }^{16}$

- за четврти разред гимназије De quoi parle-t-on aujourd'hui? аутора др Наде Петровић и мр Верана Станојевића (Завод за уџбенике и наставна средства, Београд), чије је прво издање из 1997, а треће, које смо анализирали, из 2001. године.

Увидом у наведене уџбенике дошли смо до следећих сазнања:

- и у случају уџбеника за трећи и у случају уџбеника за четврти разред, постоји само књига у којој су дати текстови, лексичка и граматичка објашњења, одговарајућа вежбања, и наставне активности ${ }^{17}$ на основу којих се развијају способности разумевања писаног текста, усмено изражавање у интеракцији и монолошко, писмено изражавање, медијација; ${ }^{18}$ нису предвиђени ни водич за наставнике, ни вежбанка за ученике, нити пратећи звучни материјал;

- оба уџбеника следе исту концепцију; у уџбенику за трећи разред, у Уводној речи аутора у којој се она подробније излаже, каже се: „Овај уџбеник има троструку намену: - учење француског говорног језика кроз новинске текстове [...]; - учење превођења са француског на матерњи језик; - проширивање знања из морфосинтаксе [...]. [...] готово свака тема је представљена на два нивоа француског језика - говорном и књижевном.” Треба истаћи ипак једну разлику између ова два уџбеника: на крају уџбеника за четврти разред додат је сегмент Vie de tous les jours, у којем су дате најважније

16 2012. године објављен је нови уџбеник за трећи разред: Quoi de neuf? аутора Сунчице Бошковић Клос, Тамаре Деспотовић Ћурчић и Вере Јовановић.

$17 \mathrm{У}$ нашем раду говорићемо о вежбама када је реч о задацима који од ученика захтевају да се усредсреди на једна конкретан језички проблем, често формалне природе; наставном активношћу сматраћемо сложеније задатке који од ученика захтевају примену когнитивних операција као што су реперисање, поређење, анализирање, синтетизовање итд.

18 Ови термини нису дати у уџбенику, већ представљају нашу класификацију датих вежбања и наставних активности. 
говорне функције (поздрављање, представљање, започињање телефонског разговора, и слично) које се, по савету аутора, обрађују „поступно уз остале целине када то наставник буде одредио"; ниво знања којем се тежи не спецификује се експлицитно; из текстова и вежбања/наставних активности може се закључити да је оно често приближно нивоу изворног говорника, али некад и средњег нивоа, па чак и почетног;

- текстови су аутентични (нису адаптирани) и бројни, како књижевни (одломци из дела аутора као што су Селин, Стендал, Монтескје, Мопасан, Мороа, Паскал, Бергсон, Сартр и други) тако и новински (преузети из француских листова, намењених одраслим образованим читаоцима, као што су Le Nouvel Observateur, L'Express, L'Evénement du Jeudi, Le Point, Le Monde, Le Figaro; неки текстови преузети су из француских уџбеника као, на примep, Bonne Route, Le Nouveau Sans Frontières III, Le Nouveau Sans Frontières IV, Sans Frontières Perfectionnement, Grand Large, као и из часописа намењених младима: Junioscopie, Presse-Papiers, Ensemble...); због те обимности, наставницима се саветује селективан приступ када је у питању настава за ученике природно-математичког смера (док граматику треба „обрадити у целини", без обзира на наставни план и на смер);

- није предвиђено развијање способности разумевања говора, чак ни у сегменту Vie de tous les jours; предвиђена су, међутим, разна вежбања интеракције између ученика - дијалози и игре по улогама;

- нису дате никакве сугестије наставнику у вези са развијањем способности разумевања говора, нити је у наставним активностима усменог или писменог изражавања предложено ученицима да претходно погледају неку емисију, филм, или да саслушају песму;

- корпус текстова који служи намени ,учење француског говорног језика" чине пре свега новински чланци и интервјуи; то опредељење указује на виђење аутора да као узор говорног језика ученицима треба дати текстове који поседују многе одлике писаног текста: дужи искази, односи координације и субординације, прецизан избор лексике, језички елементи који обезбеђују кохерентност; у тим текстовима ретко има редундантности и преформулисања, а никада нису обележене паузе, оклевања, и слично, што је честа одлика спонтаног говора. С друге стране, аутори у више наврата дају примере различитих језичких регистара, па и примере аргоа, а од ученика траже, на пример, да саржај исказан у фамилијарном регистру пренесу на стандардни.

б) Уџбеници по наставном програму за други страни језик јесу:

- за трећи разред гимназије и угоститељско-туристичке школе Француски језик, аутора Вере Костић и мр Миланке Пере (Завод за уџбенике и 
наставна средства, Београд), чије је прво издање из 2001, а треће, које смо анализирали, из 2005. године;

- за четврти разред гимназије и угоститељско-туристичке школе Француски језик, аутора Вере Костић и мр Миланке Пере (Завод за уџбенике и наставна средства, Београд), чије је прво издање из 1989, а осмо, прерађено, које смо анализирали, из 2006. године.

Увидом у наведене уџбенике дошли смо до следећих сазнања:

- као и у претходном случају, постоји само књига у којој су дати дијалози које су написали аутори уџбеника, затим текстови, песме, шале, лексичка и граматичка објашњења, одговарајућа вежбања и наставне активности помоћу којих се развијају способности разумевања писаног текста, усмено изражавање у интеракцији и монолошко, писмено изражавање, медијација; у уџбенику за трећи разред дате су и шансоне; 19 ни у случају ових уџбеника нису предвиђени ни водич за наставнике, ни вежбанка за ученике; пратећи звучни материјал у виду касета постоји, али се не може купити у књижарама Завода; на основу информације коју смо добили од уредника за француски језик, аудио касете снимане су након што су уџбеници објављени; реч је, наводно, о озвученим дијалозима и текстовима који се налазе у уџбенику, а не о осмишљеној концепцији развијања способности разумевања говора; стога не изненађује што није предвиђена ни једна вежба разумевања говора; вежбе провере разумевања прочитаног дијалога могу се, међутим, употребити у ту сврху уколико ученици слушају дијалог на касети;

- оба уџбеника следе исту концепцију и наставак су концепције уџбеника за први и други разред: аутори у Предговору истичу значај савладавања усмене комуникације „основног француског језика” (претпостављамо да је у питању ниво Б1, то јест, праг знања) и упознавања са културом и цивилизацијом Француске; исказане су и жеље да се ученици мотивишу да даље уче француски језик, да им се великим избором текстова, које прате вежбе за проверу разумевања, омогући самосталан рад, да им се пружи прилика да дају своје мишљење и друго;

- како смо већ нагласили, дијалоге, који доминирају у уџбенику, писали су аутори; текстови, предвиђени за самосталан рад, најчешће су публицистички (преузети из Figaro Magazine, Le Nouvel Observateur, Fréquence jeunes, Civilisation française quotidienne, Francoscope, La France aux mille visages, и друго; код неких текстова извор није дат), понекад књижевни (на пример, одломци из прозних дела Саган, Даниноса; песме Карема, Елијара, Тардијеа, Превера, Аполинера);

19 У интерпретацији познатих певача и кантаутора: Жилбера Бекоа, Шарла Тренеа, Жане Моро, Едит Пјаф и других. 
- ни у овим уџбеницима, подсећамо, није предвиђено развијање способности разумевања говора; и овде су предвићена разна вежбања интеракције између ученика - дијалози и игре по улогама, што индиректно може помоћи развој поменуте способности;

- нису дате никакве сугестије наставнику у вези са развијањем способности разумевања говора, нити је у наставним активностима усменог или писменог изражавања предложено ученицима да претходно погледају неку емисију или филм; будући да је у уџбенику за трећи разред у свакој наставној јединици дата по једна шансона, иако то није изричито речено, претпостављамо да се очекује да ће наставник обезбедити песму како би је ученици чули;

- корпус дијалога који су једини планирани за рад на часу, писани су стандардним француским језиком; понекад се јављају фамилијарни изрази, али понекад и конструкције које се ретко срећу у говорном језику, а чешће у писаном; опредељење аутора јесте да се за учење оног што зову ,језик комуникације", као узор говорног језика, ученицима дају дијалози који углавном јесу у духу француског језика, али не делују нарочито реалистично: реченице су неретко дуге, саговорници се савршено разумеју, нема оклевања код избора лексике, недовршених исказа; ни у овим уџбеницима нису обележене паузе; нема ни изостављања негације пе, на пример, или измене изговора личне заменице је као последице тог изостављања, нема нестајања непостојаног (па и муклог) е у неким положајима, итд; иако је идеја аутора била, без сумње, да понуде узорке спонтане конверзације, језик којим су писани можемо пре дефинисати као језик унапред планираних разговора и равномерно подељених реплика.

Као што се види из приказаног, издавач и аутори уџбеника интерпретирали су програм тако да је развијање способности разумевања говора изостављено. Такво тумачење програма потврђено је и позитивним рецензијама на основу којих је министар просвете дао решење за употребу уџбеника у настави.

Разлог занемаривања развијања способности разумевања говора у настави француског/ страних језика у нашој средини нашли смо, пре свега, у нејасном и некохерентном наставном програму. Томе треба додати и опредељење издавача за најјефтинији могући уџбеник без икаквог пратећег аудио или видео материјала, као и виђење аутора уџбеника како самог говорног језика тако и наставе и учења језика.

С друге стране, треба рећи да ако у концепцији уџбеника није присутна идеја о развијању способности разумевања говора, јесте присутна идеја о потреби да се развија знање говорног језика, иако бисмо могли да полемишемо о начину на који аутори тумаче појам говорни језик и да изразимо сумњу 
у погледу изгледа да се ученици на тај начин оспособе за стварну спонтану комуникацију са франкофоним саговорницима.

Исто тако, иако је јасно да је у питању једна, али не и једина могућа, интерпретација програма, не смемо занемарити услове у којима су ти уџбеници, посебно они за први страни језик, настали. Овакво опредељење издавача донекле је разумљиво у условима изолације земље, опште немаштине и неопремљености школа. Нови уџбеници истог издавача који су рађени 2009. и 2010. године не занемарују развијање способности разумевања говора.

\section{5. НЕКОЛИКО ДОДАТНИХ ЗАКљУЧНИХ НАПОМЕНА}

Приказ наших анализа имао је за циљ дубље упознавање елемената који у великој мери одређује наставну праксу у области страног језика, а то су наставни програми и уџбеници. Трагајући за лингвистичким и психолингвистичким теоријским основама, али и за показатељима степена унутарње кохерентности, констатовали смо да су анализирани наставни програми у значајној мери застарели и неадекватни, ${ }^{20}$ што је један од основних разлога одсуства у анализираним домаћим уџбеницима наставних активности и вежби усмерених на развијање способности разумевања говора на француском језику. ${ }^{21}$

Ови закључци указују на значај и далекосежност одлука које се доносе на нивоу државе (концепција наставних програма), али и одлука које доносе издавачи (концепција уџбеника); условљене некада мотивима сасвим удаљеним од оних који би требало да буду примарни - а то је тежња да се, ради обезбеђења што је могуће боље основе за квалитетно и ефикасно учење и наставу, траже ослонци у резултатима научних истраживања - те одлуке имају пресудан и дугорочан утицај на наставни процес.

20 Имајући у виду временске пропорције које се у стварној комуникацији посвећују различитим језичким активностима, може се уочити да је занемаривање развијања способности разумевања говора присутно и у наставним програмима других земаља, тако да неки истраживачи говоре чак о обрнутом наставном програму. Аутор појма inverted curriculum је Чарлс Свансон који је проучавао време у настави језика посвећено различитим језичким активностима: 12 година формалног образовања посвећено је увежбавању писања, 6-8 година увежбавању читања, 1-2 године увежбавању усменог изражавања и 0-1/2 године увежбавању слушања/разумевања говора (Swanson in Hyslop, Tone 1988: 1).

21 Други разлог тог одсуства јесте тадашње (реч је о деведесетим годинама 20. века) концепцијско опредељење издавача да се не израђују аудиовизуелни наставни материјали. На срећу, нови уџбенички комплети, иако настали на основу истог наставног програма, надомешћују мањкавост наставног програма захваљујући промени става издавача и спремности аутора уџбеника да уложе посебан труд у осмишљавање начина развијања способности разумевања говора на француском језику. 
Могуће је, такође, посредно увидети неусаглашеност динамике еволуције различитих нивоа нашег система образовања, што као и претходно речено има далекосежне последице, посебно због високог степена централизованости: као пример може нам послужити раскорак који у нас већ годинама постоји између основног образовања - које често трпи разне промене (пре свега наставних програма, што је праћено и одговарајућом продукцијом уџбеника) и гимназијског образовања - које одликује двадесетогодишња тромост; такво стање ствари не само да не обезбеђује континуитет у напредовању ученика, већ напротив доводи често до негирања онога што је у учењу страног језика претходило, и тиме до значајног пада мотивације код ученика.

\section{ЛИТЕРАТУРА}

Bouacha, A. A. (coord.) (1987). Vers un niveau 3. Le Français dans le Monde: numéro spécial/Recherches et applications.

Coste, D., \& Véronique, D. (coord.) (2000). La notion de progression. Paris: ENS Éditions.

Cuq, J-P. (ed.) (2003). Dictionnaire de didactique du français langue étrangère et seconde. Paris: CLE International.

Cuq, J-P., \& Gruca, I. (2005). Cours de didactique du français langue étrangère et seconde. Nouvelle édition revue et augmentée. Grenoble: PUG.

Ђурић, Љ. (2000). У прилог разноврсним моделима наставних планова и програма страних језика. Примењена лингвистика, 1, 31-40.

Ђурић, Љ. (2008). Развијање способности слушања и разумевања говора у новијим уџбеницима француског језика. Примењена лингвистика, 9, $310-321$.

Ђурић, Љ. (2008). Разумевање говора: од теорије до наставе француског језика као страног (Необјављена магистарска теза). Нови Сад: Филозофски факултет.

Eurydice. (2001). L'enseignement des langues étrangères en milieu scolaire en Europe. Преузето ca http://www.eurydice.org.

Germain, C. (2007). Evolution de l'enseignement des langues: 5000 ans d'histoire. Paris: CLE International.

Girard, D., Courtillon, N., Page, B., \& Richterich, R. (1988). Selection and distribution of contents in language syllabuses. Strasbourg: Council of Europe.

Hyslop, N., \& Tone, B. (1988). Listening: Are we teaching it, and if so, how? Bloomington: ERIC Clearinghouse on Reading and Communication Skills. 
Комисија за развој школског програма. (2003). Реформа образовања у Републици Србији: Школски програм - концепција, стратегија, имплементација. Београд: Министарство просвете и спорта Републике Србије.

Комисија за развој школског програма (2003 б). Опште основе школског програма, радни нацрт. Београд: Министарство просвете и спорта Републике Србије.

Крстић, Д. (2000). Тезе предавања Психолошке околности наставе страних језика. Примењена лингвистика, 1, 148-154.

Santos Gargallo, I. (1999). Lingüística aplicada a la enseñanza-aprendizaje del español como lengua extranjera. Madrid: Arco Libros.

Точанац-Миливојев, Д. (1997). Методе у настави и учењу страног језика. Београд: Завод за уџбенике и наставна средства.

Точанац-Миливојев, Д. (2000). Континуитет у настави и учењу страног језика. Примењена лингвистика, 1, 141-144.

Заједнички европски оквир за живе језике: учење, настава, оцјењивање. (2003). Подгорица: Министарство просвјете и науке Републике Црне Гope.

\section{Ljiljana V. Đurić}

\section{FOREIGN LANGUAGE CURRICULUM FOR HIGH SCHOOL: ANALYSIS OF A CONCEPT USING A POSTERIORI EVALUATION APPROACH}

\section{Summary}

In this work, we have analyzed the current foreign language curriculum for high school that has been used in Serbia for more than 20 years. In addition to its linguistic and psycho-pedagogic theoretical ground, we have analyzed the internal coherency and in particular the development of listening comprehension, as this element underwent significant conceptual changes in the new, communicative approach to teaching. In our analysis, we have compared curricula for the first and the second foreign language.

Furthermore, we have analyzed the interpretation of language curriculum, especially with respect to listening comprehension. We have focused on the analysis of the most important textbook publishers in Serbia and of the authors of French language textbooks.

Key words: foreign languages in Serbia, curriculum, high school, listening comprehension, textbook. 